\title{
THE PURPLE HYACINTH BEAN
}

\author{
GEORGE F. FREEMAN \\ (WITH SEVEN FIGURES)
}

Students of the genus Dolichos are now somewhat perplexed concerning the identity of D. lignosus Linn. and D. Lablab Linn. According to accepted usage, the former name applies to the smallleaved perennial vine sparingly grown as a greenhouse climber in northern climates and for arbors and trellises in warmer countries. CurTIS (Bot. Mag. I797, p. 380) states that it is perennial in England. D. Lablab is generally understood to refer to the common hyacinth bean or Bonavist, which has large purple leaves and racemes of showy purple flowers and seeds which are mottled mahogany brown to black. There are a number of varieties of this species, some of which have white flowers, white seeds, and green leaves. The size of the seed and the length and compactness of the racemes also vary strongly in the different kinds. This plant is strictly annual in the United States. It is used as an ornamental climber for porches, summerhouses, etc.

Now Prain (Jour. Asiatic Soc. Bengal $66^{2}: 429-430$. 1897) reverses the incidence of these names and makes $D$. Lablab refer to the perennial species and $D$. lignosus to the annual hyacinth bean.

In the 1895 edition of Index Kewensis, JAckson does not recognize Dolichos lignosus as a valid species, but makes $D$. lignosus Jacq. Select. Am. 205 equal D. Jacquini DC. Prod. 2:397, Ind. occ.; and he makes D. lignosus Linn. Sp. Pl. 726 equal D. Lablab Linn. Sp. Pl. 725, Reg. trop. Again, PIPER (U.S. Dept. Agric. Bull. 318. I9I5. p. 5), evidently following PraIN and Jackson, accepts the validity of D. Jacquini DC. Prod. 2:397 and assigns to this species the small perennial variety of Dolichos formerly grown in various parts of the world as D. lignosus Linn.

These references to LINNAEUS are to the edition of $\mathrm{I} 753$, which is now the recognized beginning date of the binomial nomenclature. Evidently Linnaeus considered these two species as distinct. If 
we are to follow the Index Kevensis in this matter we must assume that LINNAEUS was mistaken and that he had only two divergent forms out of the many varieties into which we now know D. Lablab to be subdivided. The evidence available, however, does not support this view, but indicates rather that the plants from which these two species were described were really specifically distinct. The original descriptions from Species Plantarum (pp. 725, 726) are as follows:

r. DOLICHOS leguminibus ovato-acinaciformibus, seminibus ovatis. Lablab hilo arcuato versus alteram extremitatem. Roy. lugdb. 368 . Hort. ups. 214.

Phaseolus aegyptius, nigro semine, Bauh. pin. 34r.

Phaseolus niger Lablab. Alp. aegypt. 74. t. 75. Vest. aegypt. 27.

Habitat in Aegypto.

Legumina dorso scabra. Caules ramique teretes, retrorsum scabri. Pedunculi semiverticillati.

9. DOLICHOS caule perenni, pedunculis capitatis, leguminibus lignosus strictis linearibus.

Dolichos caule perenni lignoso. Hort. cliff. 360. t. 20.

Phaseolus indicus perennis, floribus purpurascentibus. Eichr. carol. 36 .

Habitat . . . .

Of the identity of D. Lablab L. we have no doubt. The original description corresponds exactly with the plant grown today under the name hyacinth bean. This is further confirmed by the presence in the herbarium of the Linnean Society of London of a specimen of this plant identified and written up by LINNAEus himself. In fig. I is given a tracing of this specimen which was very kindly furnished by the general secretary of the Linnean Society. ${ }^{x}$ The identity of this plant with the common hyacinth bean is evident. Compare fig. 2, which is a photograph of a specimen grown by the writer. The references given by LINNAEus to "Bauh. pin. 34I" and "Alp. Aegypt. 74 t. 75 " have been examined and leave no doubt but that they refer to the common hyacinth bean. The reference to "Roy lugdb. 368 , Hort. ups. 2 I4" has not been available.

I This tracing was kindly obtained for the writer by Dr. OAkEs Ames of Harvard University. 
The confusion has evidently arisen on account of the uncertainty as to the identity of the plant described by Linnaeus as D. lignosus. There is no cut accompanying this description, but LiNNAEUS refers to an earlier publication by himself (Hort. Cliff.

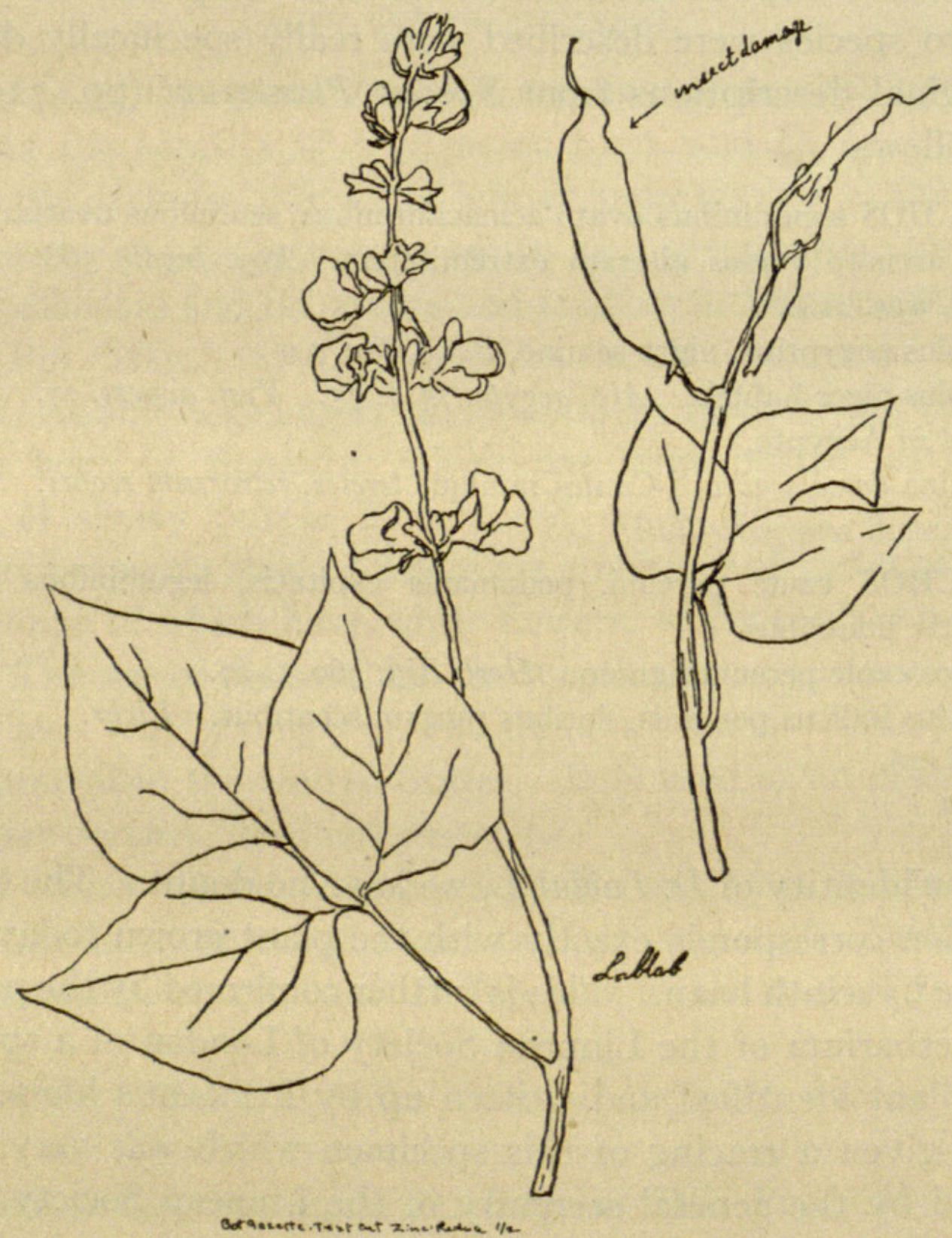

FIG. I. - Tracing of specimen of Dolichos Lablab identified and described by LinNaEus; from specimen in herb. Linnean Society.

360. t. 20) and to "Eichr. Carol. 36." This latter publication has not been available, but the former has been examined carefully. Fig. 3 is a reproduction of a photostat copy of LinnaEus' figure in Hort. Cliff. 360 t. 20 . The description accompanying this plate was much more full and complete than that in the Species Plantarum of $\mathrm{I} 753$, and moreover was evidently made from a 


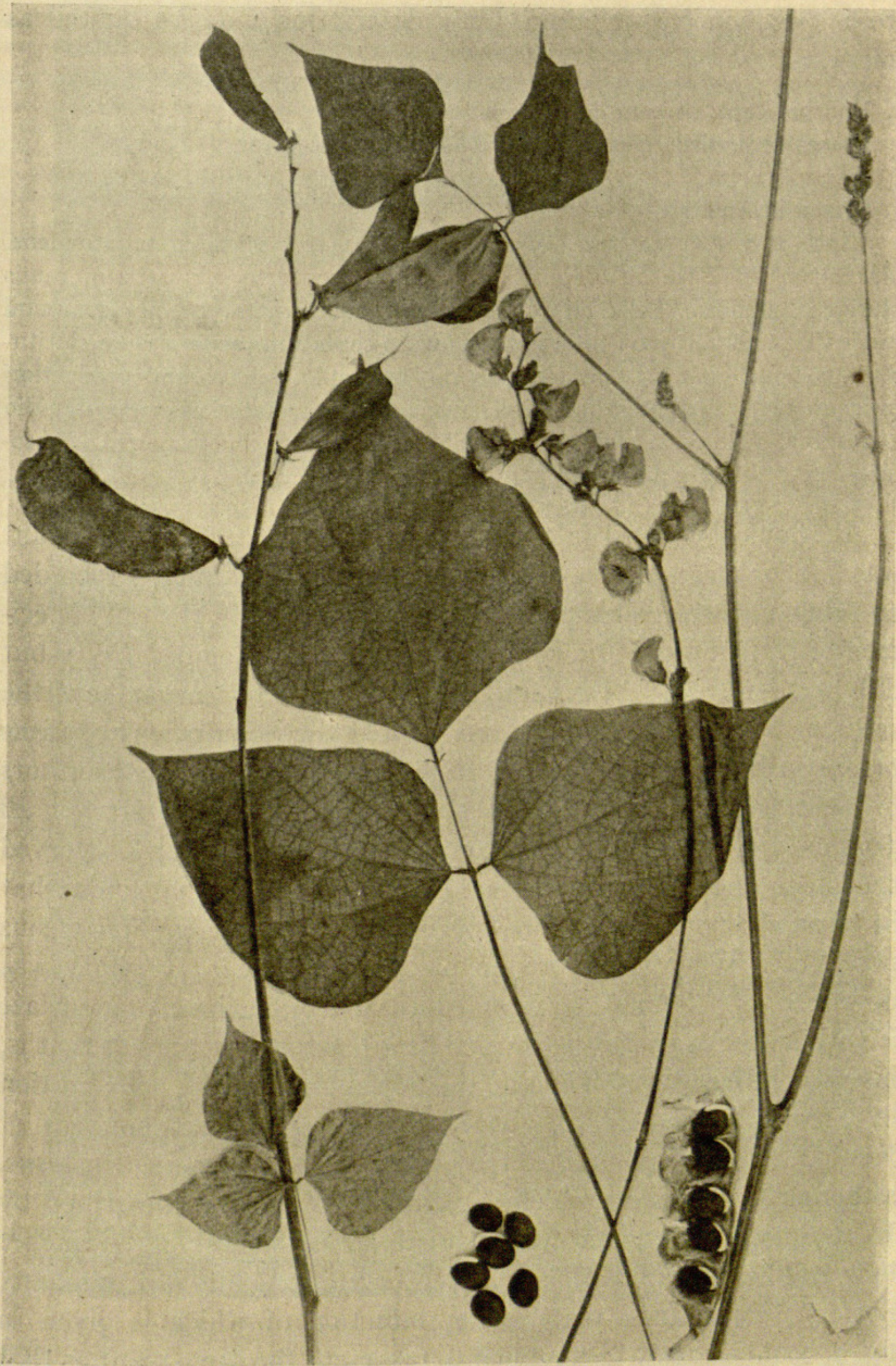

Fig. 2.-Purple hyacinth bean (Dolichos Lablab): photograph of specimen grown at University of Arizona, IgI4. 
fresh specimen before him. This description may be quoted as follows:

2. Dolichos caule perenni lignoso. Vide Tab.

Phaseolus indicus perennis, floribus purpurascentibus. Hort.

Carolsrb. 36.

Crescit in America.

Ante accessum nostrum enata fuit planta frutescens arcte scandens, plus quam homanae altitudinis; caule tereti, contorto, vix striato, ramis plurimis tenuibus. Folia ad ramorum exortum ternata, petiolo communi insidentia, quorum quod intermedium ovato-cordatum, acuminatum, latitudin pollicis, glabrum, petiolo proprio quaduplo reliquorum productiori insidens; lateralia latere exteriori magis dilatata, interiori vero dimidio angustiora. Flores in pedunculo pauci, corolla rubra seu purpurea. Absoluta florescentia absque fructu periit.

It should be noted in this description that although the plant was $6 \mathrm{ft}$. or more, the leaves were but $\mathrm{I}$ inch wide and are recorded as being smooth. This plant, which was probably the only specimen of $D$. lignosus actually seen by LinNaEus, bloomed freely but did not set seed. Linnaeus therefore probably never saw the seeds or pods of this species, but quoted the descriptions of these organs in his later publications from descriptions by other authors of plants which he assumed to be of the same species. Here in all probability lies the source of confusion. LinNaEus had observed that his $D$. Lablab was an annual in Europe and did not know that in warmer countries this same species may persist as an herbaceous perennial. When therefore he met with a Dolichos which was described as perennial, he would naturally be inclined to associate it with a species of Dolichos which he knew to be perennial, that is, his own $D$. lignosus. Thus he made the error in the ${ }_{17} 63$ edition of Species Plantarum (p. 1022) of citing Phaseolus perennis of Rümph. Amb. 5, pp. 378 t. I36, as a synonym of his D. lignosus, although this species (which is clearly D. Lablab) is described by RÜMPHIUS, in the publication named, as having leaves $3^{-4}$ inches long and nearly as broad, with racemes $\mathrm{I} \mathrm{ft}$. long and bearing many flowers. RüMPHIUs' plate, a reproduction of which is given in fig. 4, could scarcely be assumed to represent the same plant as that of $D$. lignosus in Hort. Cliff. 360 . The only point of similarity is in 


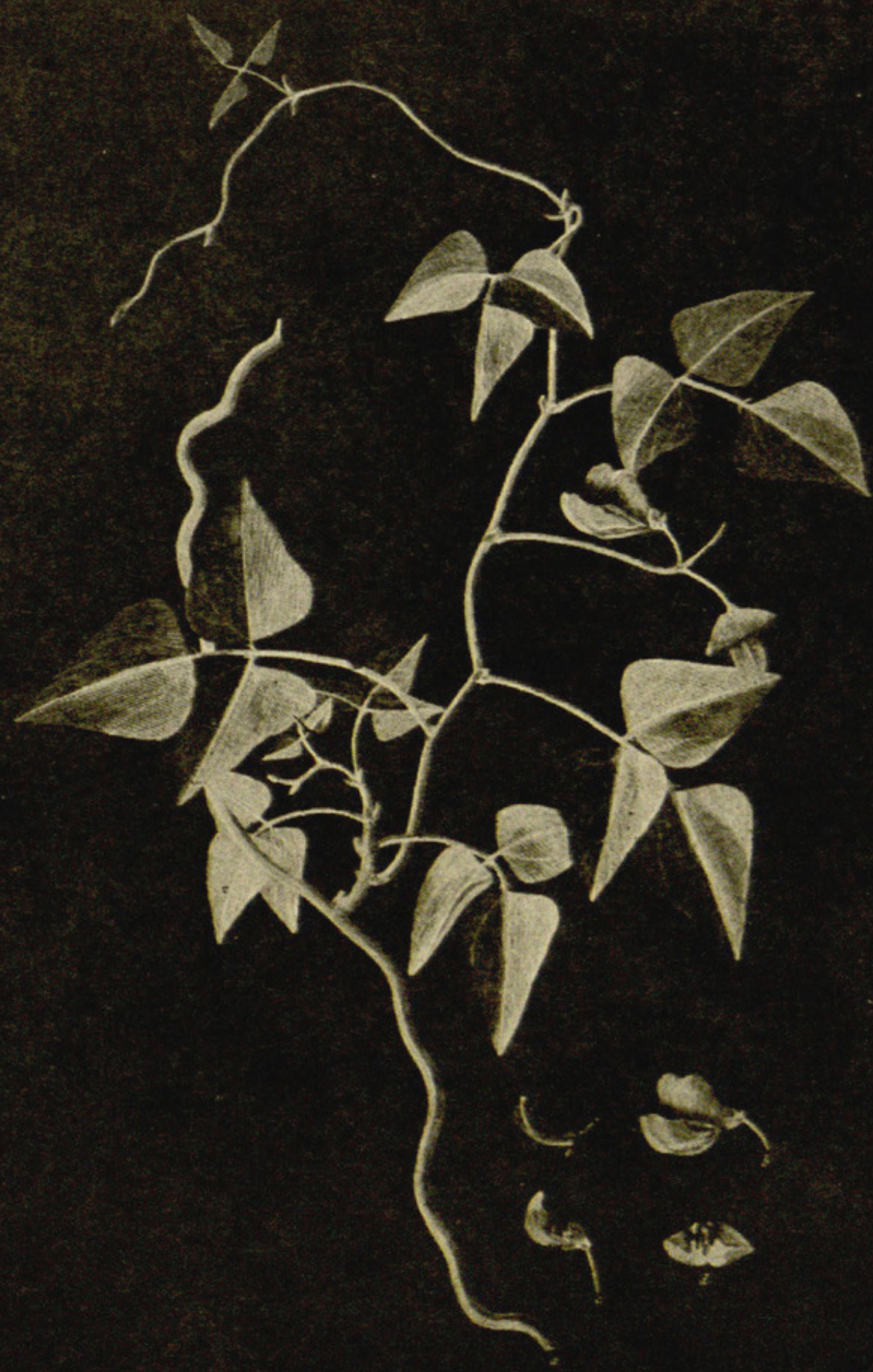

DoL I CHOS caule perenni lignoto. Hort. Chif. 360. P. 2.

a. Casulistranatess cam anaco ramo,

b. Flas intrger.

c. Calix ctini Cardie carina.

d Corelle Vexultane refapinatsan.

c. Filanowia nocem coulate in singinass.

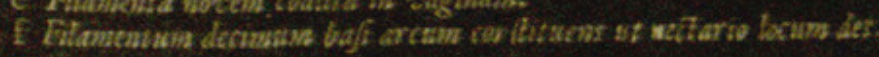

6. D. Lantide

Fig. 3.-Dolichos lignosus Linn.: from photostat copy of Linnaeus' figure in Hortus Cliffortianus. 
the flower clusters, and here the descriptions show these to be entirely distinct (see legend to fig. 4).

Turning to the descriptions and plates left by other botanists of the immediately succeeding decades we find in JACQUIN Selectarum stirpium Americanarum historia $\left(\mathrm{I}_{7} 6_{3}\right)$ a plant described as D. lignosus. Citations to the D. lignosus of Linn. Sp. Pl. 726 and Linn. Hort. Cliff. 360 . t. 20 are given with question marks, indicating that the author doubted that the plant he described was the same as that described by LiNNAEus. An examination of his description makes it clear that the two plants were entirely different, for the plant of JACQUIN had pilose stems and pods, peduncles shorter than the scabrous leaves, white flowers, and pods $3^{-4}$ inches long, containing about 18 seeds, whereas, as we shall see, the plant described by LINNAEUs had nearly smooth stems, pods, and leaves, peduncles longer than the leaves, purple flowers, pods I-2 inches long with 7 or 8 seeds at the most.

AIton (Hort. Kew. 3:31, 33. I789) recognizes both D. Lablab L. and $D$. lignosus $\mathrm{L}$. and gives practically the same descriptions as are given by LinNaeus. He states that $D$. lignosus was introduced into England in 1776 by Monf. Thourn.

In 1792 Sмiтн (Spicilegium Bot. no. 2, Gleanings of Botany, pp. I9 and pl. 2r) describes and pictures a plant which he calls D. lignosus. Sмiтн's plate is here reproduced in fig. 5 and his description is so clear and concise that it is quoted in full as follows:

\section{TABLE XXI}

Dolichos lignosus. Purple woody Dolichos. Diadelphia Decandria. Stigma downy.

GEN. CHAR. Standard marked at its base with two parallel oblong tubercles, compressing the under side of the wings.

Section I. Climbers

Spec. CHAR. Stem climbing, perennial. Flowers in little heads. Pods straight, linear.

Syn. Dolichos lignosus Linn. Sp. PI. 1022. Hort. Cliff. t. 20. Ait. Hort. Kew. V. 3.33.

A native of the East Indies.

Root woody, perennial. Stem woody, supple, climbing, much branched, roundish, striated, smooth; branches alternate, very long and slender, but 


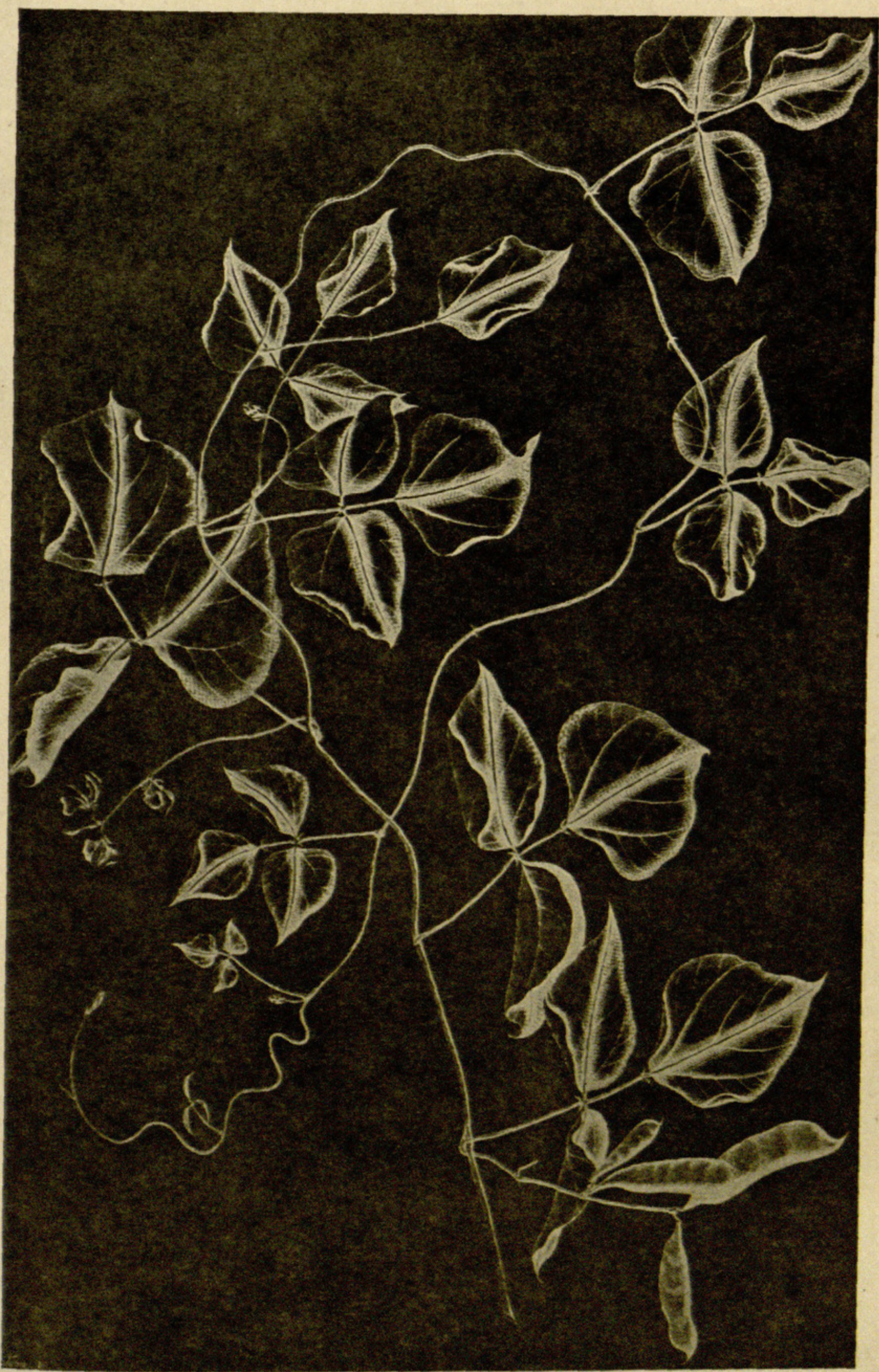

FIG. 4.-Phaseolus perennis Rümph. Amb. 5. 378. t. 136: the description accompanying this plate states that the racemes are I $\mathrm{ft}$. long and many-flowered; plant here represented is undoubtedly $D$. Lablab Linn. 
little subdivided, round, striated, somewhat downy, leafy, many-flowered. Leaves alternate, on long footstalks, ternate, or rather binate with an odd one.

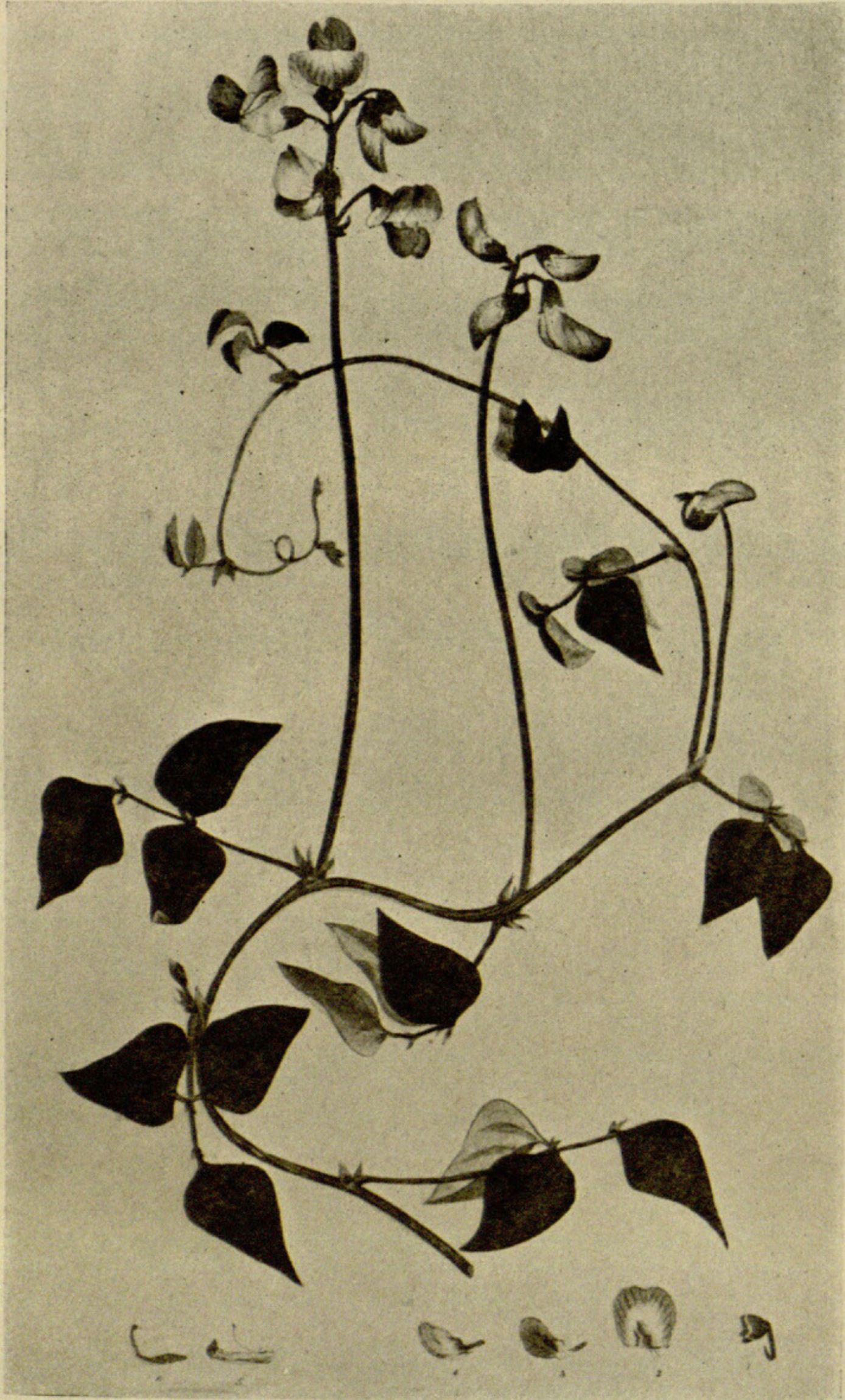

Fig. 5.-Dolichos lignosus: reproduction of pl. 21, J. E. SмrтH, Spicilegium Bot. no. 2. Gleanings of Botany. 1792 . 
Common footstalk roundish, channeled above, swelling and purplish at the base; partial ones very short, swelled, incurved. Leaflets rhomboid, elongated, acute, entire, obsoletely 3 -nerved; bright green and shining above; glaucous beneath. Stipulae entire, sharp, somewhat triangular, downy on the margin, dark purple at the base; of which 2 larger ones are placed at the bottom of the common footstalks, and 2 smaller, lanceolate, at the insertion of the partial footstalks. Clusters axillary, solitary, erect, each having from 3 to 6 flowers in a little head. Common flowerstalk simple, very long, striated, angular in the upper part; partial ones generally 2 together, short, downy, single-flowered.

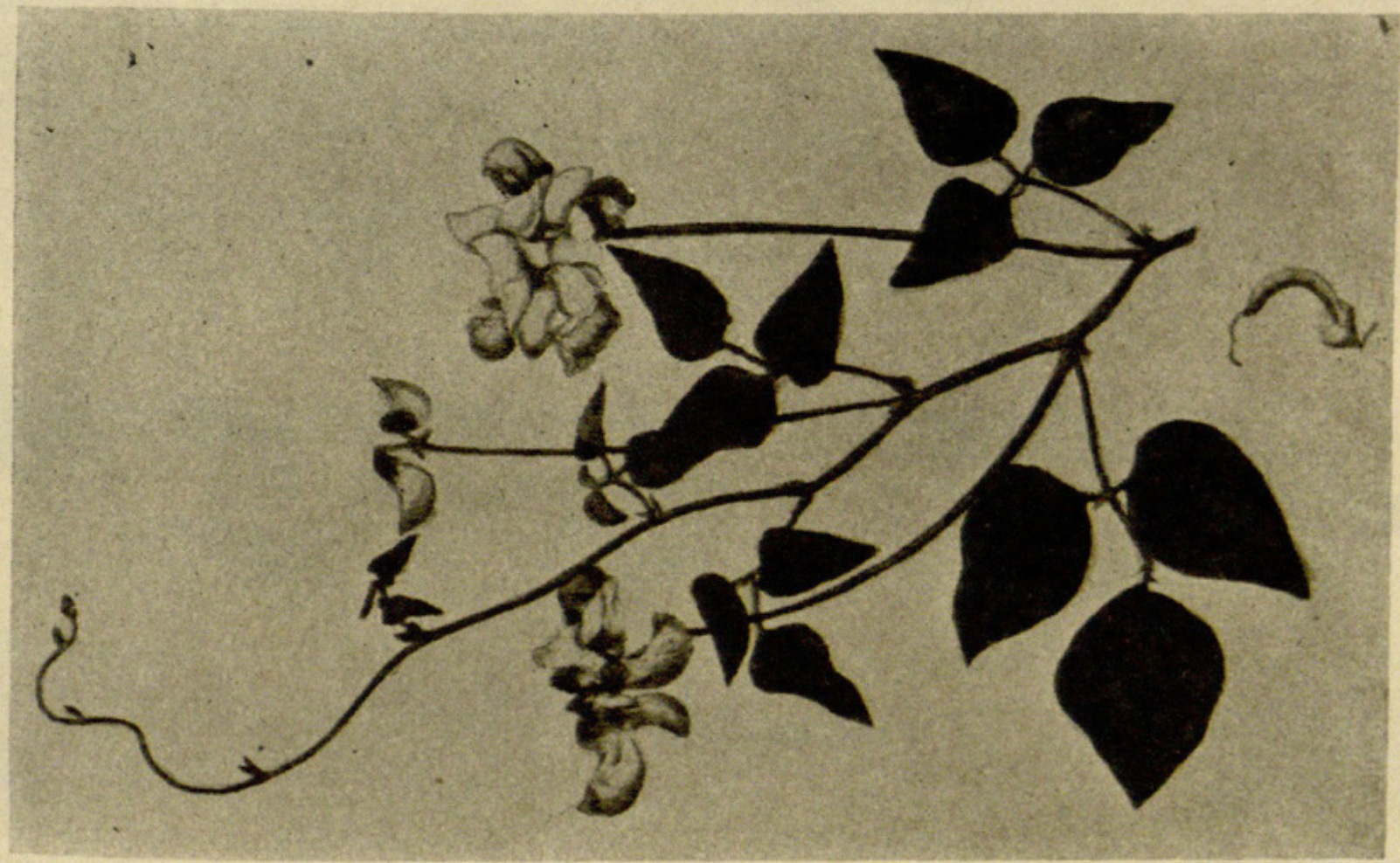

Fig. 6.-Dolichos lignosus: from photograph of colored plate in CuRTIs' Bot. Mag. 2:380. 1797 .

Bracteae lanceolate, acute, hairy. Flowers somewhat drooping, rose coloured with a purplish keel. Calyx smooth, thickly ciliated in the margin. Pod an inch long, a little recurved, brownish, smooth. Seeds black.

According to Arton, this beautiful plant was introduced from the French gardens to our own in 1776 . It is easily propagated by seed, and in a stove produces abundance of flowers during the summer.

A little study of Smrth's plate and descriptions shows that it agrees very closely with the plate and description of $D$. lignosus of LinNaEus and that it cannot possibly be the D. lignosus of JACQUIN.

Five years later, in CURTIs' Bot. Mag. II:380. I797, is found a description and plate of D. lignosus, which is reproduced in fig. 6 . 
Comparing the plate and description with those of SMITH and Linnaeus, there is no doubt that they all had the same plant. Finally, fig. 7 is made from a fresh specimen of plants grown at the University of California. This plant agrees perfectly with SмIтн's description and with every essential part of the description and

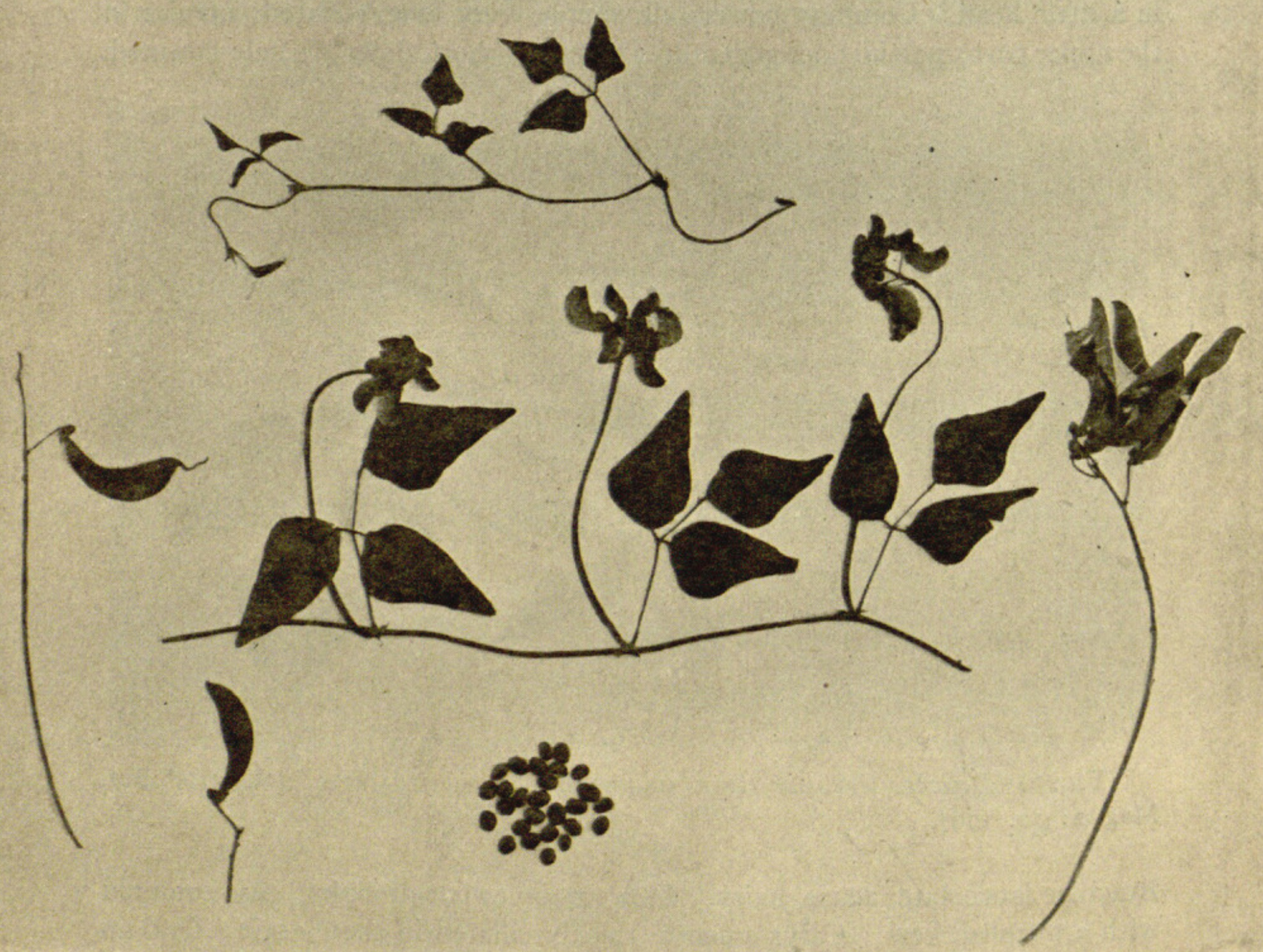

FIG. 7.-Dolichos lignosus: from photograph of fresh specimen furnished by Professor GREGG, University of California, January r914.

plate by LinNAEus except that in which he states that the pods are straight. When we remember that LINNAEUs probably never saw the pods of this species, such a discrepancy is not surprising.

Misled by the error of LinnaEus in ascribing straight pods to his D. lignosus, DECANdolle (Prod. 2:397. I825) makes the D. lignosus of Curtis (Bot. Mag. t. $382^{2}$ ) a variety of D. lignosus Linn. He moreover corrects the error made by JACQUIN in assign-

${ }^{2}$ This is an error by DECANDOLLE, and should read 380 . 
ing his plant (described in Select. Stirp. Amer. Hist. I763, p. 205) to D. lignosus $\mathrm{L}$. by calling this plant $D$. Jacquini. To emphasize the justice of this disposition of the 2 species by DECANDOLLe, the original description furnished by JACQUIN may be quoted as follows:

Planta perennis, volubilis, tota pilosa; praecipue vero rami inferiores lignosi, and legumina, pilis hispida sunt. Foliola sunt ovata, acuta, scabriuscula, duos pollices longa, lateralibus interne obliteratis. Stipulae ex lanceolato ovatae, acuminatae, basi emarginatae. Pedunculi umbellati, foliis breviores, pauciflori. Flores albidi. Legumina tres quatuorve pollices longa, acuminata, stricta, ad apicem leviter incurva; teretia, nec torosa, pilossissima fusca, interne nivea. Semina circiter octodecem, nitida, atra cum hilo albido, parva, compressiuscula, ex oblongo reniformia.

Habitat in Caribaearum sylvaticis.

It would be difficult to harmonize this description with that of either Smith (Spic. Bot. no. 2, p. I9) or Linnaeus (Hort. Cliff. 360. t. 20). We must conclude, therefore, with DECANDolLE, that it is a distinct species and follow him in calling it D. Jacquini DC. Prod. 2:397.

In the opinion of the writer, the evidence presented herewith is sufficient to show that the plants described as $D$. lignosus by Linnaeus (Sp. Plant. ed. I, I753, p. 726), and more fully in his earlier work (Hort. Cliff. 360. t. 20. I737), by J. E. Sмттн (Spic. Bot. no. 2, p. I9, pl. 21. I792), by Curtis (Bot. Mag. II:380. I797), and the plant now grown in various parts of the world as $D$. lignosus and shown in fig. 7 are all one and the same species, which is distinct from $D$. Lablab L. We are therefore unable to follow either JACKSON (Index Kewensis I895) in making D. lignosus L. a synonym of D. Lablab L; PraIN (Jour. Asiatic Soc. Bengal $66^{2}: 429-430$. 1897$)$ in reversing the incidence of the original Linnaean names by making $D$. Lablab L. refer to the perennial species and D. lignosus $\mathrm{L}$. to the annual hyacinth bean; or PIPER (U.S. Dept. Bull. Agr. 3 18. I915, p. 5), in assigning the plant commonly grown as $D$. lignosus L. to D. Jacquini DC. On the other hand, we must hold to the original Linnaean designation of the common annual (frequently perennial in tropical countries) hyacinth bean (and its many varieties, fig. 2) as D. Lablab L., and the more slender perennial greenhouse (in northern climates) climber shown in fig. 7 as $D$. lignosus $\mathrm{L}$. 


\section{$2 \mathrm{BHL}$ Biodiversity Heritage Library}

Freeman, George F . 1918. "The Purple Hyacinth Bean." Botanical gazette 66(6), 512-523. https://doi.org/10.1086/332374.

View This Item Online: https://www.biodiversitylibrary.org/item/109341

DOI: https://doi.org/10.1086/332374

Permalink: https://www.biodiversitylibrary.org/partpdf/224091

\section{Holding Institution}

Missouri Botanical Garden, Peter H. Raven Library

\section{Sponsored by}

Missouri Botanical Garden

\section{Copyright \& Reuse}

Copyright Status: Public domain. The BHL considers that this work is no longer under copyright protection.

This document was created from content at the Biodiversity Heritage Library, the world's largest open access digital library for biodiversity literature and archives. Visit BHL at https://www.biodiversitylibrary.org. 